\title{
Leaching characteristics of fly ash from fluidized bed combustion thermal power plant: Case study: Çan (Çanakkale-Turkey)
}

\author{
Alper Baba ${ }^{\mathrm{a}, *}$, Gulbin Gurdal ${ }^{\mathrm{b}}$, Fatma Sengunalp ${ }^{\mathrm{b}}$ \\ a Izmir Institute of Technology, Engineering Faculty, Department of Civil Engineering, 35430, Izmir, Turkey \\ b Canakkale Onsekiz Mart University, Engineering Faculty, Department of Geological, 17020, Canakkale, Turkey
}

\section{A R T I C L E I N F O}

\section{Article history:}

Received 23 January 2010

Received in revised form 19 March 2010

Accepted 19 March 2010

\section{Keywords:}

Power plant

Fly ash

Leaching

$\mathrm{pH}$ and temperature

\begin{abstract}
A B S T R A C T
It is known that the concentration of elements of fly ash varies due to the used-coal and the used-lime qualities varying in different periods. In the Çan Thermal Power Plant (CTPP) located at northwestern Turkey, Çan (Çanakkale) basin coals, which are classified as lignite to sub-bituminous $C$ coal with high total sulphur (0.4-12.22\%) and a broad range of ash contents (3.2-44.6\%) are mainly used. Performed studies reveal that some toxic elements exit in the coal, including As, $\mathrm{U}$ and $\mathrm{V}$. Also, while the As, $\mathrm{Cu}, \mathrm{Co}$ and $\mathrm{Hg}$ contents in coal increases, the sulphur contents in coal also increase. Additionally, trace elements that have inorganic compounds in coal are mobilized into air during the combustion process. This poses a big risk for human health and keeping the environment when Çan Basins low quality lignite is burned, it's the fly ash that contains several toxic elements which can leach out and contaminate the water resources.

In this study, toxicity tests were conducted on the fly ash samples that were obtained from the fluidized bed combustion of Çan Thermal Power Plant. The results showed that water temperature, $\mathrm{pH}$ and the quality of the limestone used were the most important factors affecting the leaching properties. Concentration of some toxic elements found in the fly ash, such as; $\mathrm{As}, \mathrm{Cd}, \mathrm{Cr}$, Pb, Se and $\mathrm{Zn}$ were analyzed. Concentration richness of some heavy metals were attributed to the increase of water temperature, especially when pH is lower than 5 . At $\mathrm{pH}=5$ value, there is no clear explanation of each heavy metal presence in the fly ash from fluidized bed combustion thermal power plant.
\end{abstract}

(c) 2010 Elsevier B.V. All rights reserved.

\section{Introduction}

Use of lignite in coal combustion power generation process lead to increased environmental problems associated not only with gaseous emissions, but also with the disposal of ash residues. In particular; use of low quality lignite with high ash content, results in huge quantities of fly ash to be disposed. One main problem related to the coal ash disposal is the heavy metal content of the residue. As lignite burns, toxic pollutants such as arsenic (As), lead ( $\mathrm{Pb})$, zinc $(\mathrm{Zn})$, selenium $(\mathrm{Se})$, cadmium $(\mathrm{Cd})$, cobalt $(\mathrm{Co})$, nickel $(\mathrm{Ni})$, copper $(\mathrm{Cu})$ and chromium $(\mathrm{Cr})$ are transferred into the wastes. Of these wastes, especially the fly ashes, cling to the surface of the elements [1-3]. These toxic pollutants can leach out and contaminate soils, as well as surface water and groundwater [2,4-12]. Fluidized bed combustion technology is a clean and effective technology to burn coals with high sulphur and ash contents, but with low calorific values. The most significant advantage of this technology is to minimize the emissions of sulphur dioxide $\left(\mathrm{SO}_{2}\right)$ and nitrogen oxides $\left(\mathrm{NO}_{x}\right)$. The desulphur-

\footnotetext{
* Corresponding author.

E-mail address: alperbaba@iyte.edu.tr (A. Baba).
}

ization process is being realized directly within the burner, by addition of limestone during combustion [13].

Early-Middle Eocene aged Çan coal basin is located at northwestern Turkey (Fig. 1). This area is exploited mainly by opencast mining (Çan Turkish Coal Enterprise) and feeds nearby Çan Thermal Power Plant (CTPP) with a $2 \times 160$ (320) MW capacity. In the Çan basin, total reserves are $100 \mathrm{Mt}$ and its lignite seam has $17 \mathrm{~m}$ average thickness [14]. The annual average lignite need of this plant is 1.82 million tons. A fluid coal-fired thermal power plant has been in operation since 2005 in Çan and currently it produces almost half a million tones of fly ash per year. Studies show that fly ash is enriched by many trace elements, particularly metals as found in this thermal power plants ash [15]. These elements may be surface adsorbed on the glassy spherical fly ash particles. Elements that are surface adsorbed can be quite mobile. Leaching of these trace elements from wastes is also controlled by the trace element concentration in coal and their modes of occurrence in coal [16-19].

The aim of this study to determine the leaching characteristics of the fly ash as from the CTTP and its controlling parameters. To this end, some fly ash samples which are taken in 2008 from the CTPP have been examined in terms of heavy metal leach ability under various experimental methods, in order to determine the effects of the water temperature, $\mathrm{pH}$ and limestone. Additionally, coal characterization 


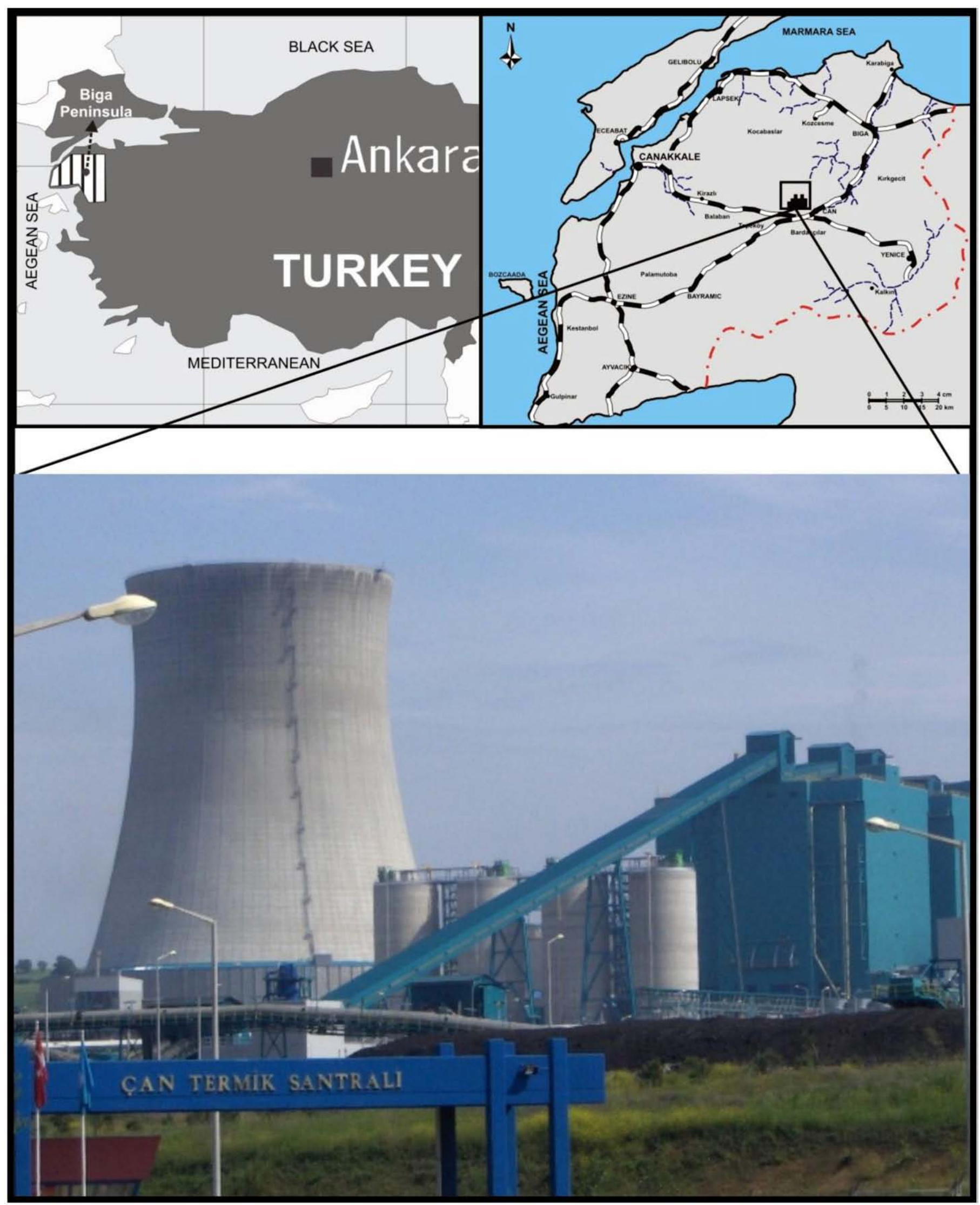

Fig. 1. Location map of study area and view of Çan Thermal Power Plant. 
and quality parameters have been summarized using the existing data [15,20-23].

\section{Materials and methods}

Fly ash samples used in this study were collected from the CTPP in 2008. A sample weighting $5 \mathrm{~kg}$ was taken under the electro filter. The samples were not subject to any preparatory operation at the plant. Standard proximate analyses of the fly ashes were carried out according to the procedures of the American Society for Testing and Materials [24]. The chemical analyses (major and trace elements) of the fly ash samples were carried out by inductively coupled plasma atomic emission spectrometry (ICP-AES) and ICP mass spectrometer at the ACME Analytical Laboratories, Canada. Scanning electron microscopy with energy-dispersive X-ray microanalysis (SEM-EDX) technique was used to determine morphology of the ash at the Izmir Institute of Technology in Izmir, Turkey.

For the coal characterization process, there were some previous studies [20,21]. The basic parameters of Miocene coals from the Çan Basin have been studied by using proximate, ultimate and geochemical analyses. A total of 83 coal samples, some taken from the drill cores and some others from the open pit mine were evaluated. The coal samples were taken from various mining areas in the basin, namely; Çan Center, Etili, Yayaköy, Çomaklı and Yeniçeri. These samples were obtained from the drill holes or from the seams of the open mines at the Çan Basin. Samples from the open mines were collected using a channel-profile sampling strategy.

Proximate analyses of 64 coal samples have been determined using the ASTM standards [25] at the Çan Turkish Coal Enterprise Coal Laboratory. The moisture, volatile matter and ash contents were determined by the LECO TGA 160 device according to the ASTM D $3173,3174,3175$ procedures, respectively. The calorific values were determined by LECO AC 350 instrument using the ASTM D 5865 procedure. Total sulphur analyses were carried out using LECO SC 132 (ASTM D 4239). Ultimate analysis of the selected 14 coal samples were performed using an ASTM D 5373 (LECO CHON 1000) procedure at the General Directorate of Mineral Research \& Exploration (MTA) Analysis Laboratories in Ankara, Turkey.

The transfer of the heavy metals from the ash into the water can be evaluated by many experimental methods. In order to determine the toxicity of the heavy metals, American Society of Testing and Materials' (ASTM) Method-A Extraction Procedure was used. The obtained leaching solutions were analyzed by the ICP-AES at the Central Laboratory of the Çanakkale Onsekiz Mart University in Çanakkale, Turkey.

Sample leaching procedure used in the laboratory was as follows.

A $50 \mathrm{~g}$ fly ash sample was weighed on the GE 212 Sartorius precision scale and placed into a glass container. Then, $200 \mathrm{ml}$ ultra deionized pure water with $\mathrm{pH}=7$ was added. Following the water addition, the $\mathrm{pH}$, electrical conductivity and total dissolved matter values were measured with the Hanna brand $\mathrm{HI} 9812-5$ Portable $\mathrm{pH} / \mathrm{Ec} / \mathrm{TDS} /{ }^{\circ} \mathrm{C} \mathrm{pH}$ meter. The samples were then placed into the Memmert brand incubator at $10{ }^{\circ} \mathrm{C}$ and $20^{\circ} \mathrm{C}$. Later they were placed into the drying oven at $30{ }^{\circ} \mathrm{C}$ and $40{ }^{\circ} \mathrm{C}$ for $24 \mathrm{~h}$. Then drawn through the filter paper and $\mathrm{As}, \mathrm{Co}, \mathrm{Cr}, \mathrm{Cu}, \mathrm{Ni}, \mathrm{Pb}, \mathrm{Se}$ and $\mathrm{Zn}$ values are found with the help of Varion brand Liberty $\mathrm{AX}$ Sequential-ICP-AES. The same procedure is repeated with $\mathrm{pH}=3$ and $\mathrm{pH}=5$ water. Hydrochloric acid $(\mathrm{HCl})$ was used for dilution.

Trace elements were analyzed at the ACME Canada Analytical Laboratory by inductively coupled-plasma mass spectrometry (ICP-MS) and inductively coupled plasma-atomic emission spectroscopy (ICP-AES) devices using different analytical procedures.

\section{Results and discussion}

\subsection{Characterization of the coal from the Çan Basin}

The results of proximate and ultimate analyses of Çan coals are summarized in Table 1. From the determined coal parameters, the
Table 1

Variations in geochemical properties of the Çan coals obtained from proximate and elemental analyses.

\begin{tabular}{lc}
\hline Parameters & Value \\
\hline Moisture (o,\%) & $8.80-36.20$ \\
Ash (db \%) & $3.20-44.60$ \\
Volatile matter (daf, \%) & $45.50-61.50$ \\
Gross calorific value (maf, kcal/ kg) & $3419-6479$ \\
Total sulphur (o,\%) & $0.40-12.20$ \\
C (daf) & $56.48-80.19$ \\
H (daf) & $4.09-5.78$ \\
N (daf) & $0.68-1.89$ \\
O (daf) & $0.85-20.89$ \\
S & $7.77-26.09$ \\
\hline
\end{tabular}

o: original, db: dray basis, daf: dry ash free, maf: moisture ash free.

a Calculated by subtraction $0: 100-(\mathrm{C}+\mathrm{H}+\mathrm{N}+\mathrm{S})$.

volatile matter content (dry ash free basis) and the gross calorific value (moisture ash free basis) are evaluated for coal rank classification in the basin using the ASTM classification [26].

For the Çan basin coals, moisture and fly ash content vary from 8.8 to $36.2 \%$ on original basis and from 3.2 to $44.6 \%$ on dry basis, respectively. The volatile matter content of the coals indicates existence of a broad range of values ranging from 45.5 to $62.2 \mathrm{wt} . \%$ (dry ash-free basis). The gross calorific values vary from 3419 to $6479 \mathrm{kcal} / \mathrm{kg}$ (moisture ash free basis). Total sulphur contents range from 0.4 to $12.2 \%$. Both parameters indicate that the rank is a lignite transitional to sub-bituminous A range.

A total of 47 trace and rare elements (REE) are determined. But only As, B, Ba, Be, Cd, Cu, Co, F, Hg, Mo, Ni, Pb, Sb, Se, Sn, Th, Tl, V, U and Zn were evaluated, because of their environmental and human health concerns. Among these elements; As, Be, Cd, Cr, Co, Hg, Mn, Ni, Pb, Sb, Se, and radionuclide (e.g., Th and $\mathrm{U}$ ) are also identified as being potentially Hazardous Air Pollutants (HAPs) by The U.S. Clean Air Act Amendments (1990). Variations of trace element concentrations are given in Table 2. The concentrations of these elements are generally within the allowed hazardous risk range. However, the As (max. 6413.8 ppm.), U (max. $64.5 \mathrm{ppm}$ ) and $\mathrm{V}$ ( $\max .459 \mathrm{ppm}$ ) and contents in some coal samples are higher than the world coal value. In general, the average values are slightly higher than the world coal value. However, extra care should be taken in order not allow subsurface contamination Elemental modes of occurrence in coal are treated by using correlation data with the element concentration, ash and sulphur contents. All these elements are

Table 2

Concentration ranges of the potential hazardous elements in the Çan coals (results are compared to the ranges for most world coals from Swaine [18] and Palmer et.al. [28]).

\begin{tabular}{lccc}
\hline Trace elements & $\begin{array}{l}\text { Çan coals } \\
(\mathrm{ppm})\end{array}$ & $\begin{array}{l}\text { World coals }[18] \\
(\mathrm{ppm})\end{array}$ & $\begin{array}{l}\text { Turkish coals (all of Turkey) } \\
{[28](\mathrm{ppm})}\end{array}$ \\
\hline $\mathrm{As}$ & $1.4-6413.8$ & $0.5-80$ & $1.8-620$ \\
$\mathrm{~B}$ & $97.3-656$ & $5-400$ & $22-1200$ \\
$\mathrm{Ba}$ & $12.20-735$ & $20-1000$ & $15-590$ \\
$\mathrm{Be}$ & $1-<0.5$ & $0.1-15$ & $0.15-0.63$ \\
$\mathrm{Cd}$ & $0.1-<0.2$ & $0.1-15$ & - \\
$\mathrm{Cu}$ & $1.9-67.5$ & $0.5-50$ & $1.5-100$ \\
$\mathrm{Co}$ & $0.1-74.2$ & $0.5-30$ & $0.87-51$ \\
$\mathrm{~F}$ & $<10-730$ & $20-500$ & - \\
$\mathrm{Hg}$ & $0.01-0.27$ & $0.02-1$ & $0.03-0.66$ \\
$\mathrm{Mo}$ & $0.1-41.60$ & $0.1-10$ & $0.43-69$ \\
$\mathrm{Ni}$ & $0.8-40.1$ & $0.5-50$ & $3.1-1600$ \\
$\mathrm{~Pb}$ & $0.7-97$ & $2-80$ & $0.95-58$ \\
$\mathrm{Se}$ & $<0.5-7$ & $0.2-10$ & $0.045-24$ \\
$\mathrm{Sb}$ & $<0.1-1.5$ & $0.05-10$ & $0.12-41$ \\
$\mathrm{Sn}$ & $0.09-4$ & $1-10$ & - \\
$\mathrm{Th}$ & $0.3-35.2$ & $0.5-10$ & - \\
$\mathrm{Tl}$ & $<0.1-0.4$ & $<0.2-1$ & - \\
$\mathrm{U}$ & $0.5-64.5$ & $0.5-10$ & $0.32-140$ \\
$\mathrm{~V}$ & $29-459$ & $2-100$ & $5.5-270$ \\
$\mathrm{Zn}$ & $3-524$ & $5-300$ & $5.8-260$ \\
\hline
\end{tabular}




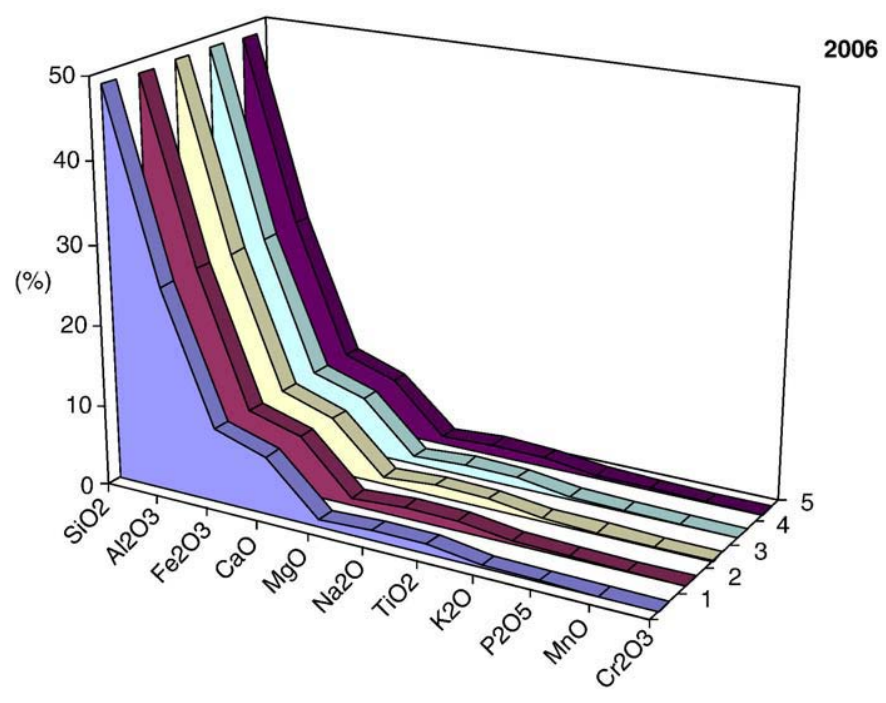

Fig. 2. Chemical composition of fly ash in Çan Thermal Power Plant.

inorganic affinities, except the V element. Also, the concentrations of trace elements and their associations show heterogeneity within the coal samples, depending on their source areas. The enrichment of sulphur content in the coal samples also seen similar to the enrichment of As in the same coal samples.

\subsection{Chemical and geochemical properties of the fly ash}

Fly ash samplings have been performed in two different stages before the flue gas desulphurization unit was not active and after the unit was online (after 2007). The first fly ash samples were taken in 2006 during when flue gas desulphurization unit was not operative and no limestone addition was done. Consequently, during this time $\mathrm{CaCO}_{3}$ levels in the ash were comparably low. The results of the chemical analysis of these ash samples show that the ashes of CTPP contain more than $70 \% \mathrm{SiO}_{2}(\%)+\mathrm{Al}_{2} \mathrm{O}_{3}(\%)+\mathrm{Fe}_{2} \mathrm{O}_{3}$ (\%), (average $83.05 \%$ ) and $\mathrm{CaO}(\%)$ was less than $10 \%$ (average $7.09 \%$ ) (Fig. 2). Based on the results of these analyses, the fly ashes were classified as type F, which have low calcareous and pozzolanic (bonding) characteristics [1]. After flue gas desulphurization unit was taken online and limestone was started to be added, the composition of ash was completely changed. The chemical composition of the fly ash from the CTPP contained less than $70 \% \mathrm{SiO}_{2}(\%)+\mathrm{Al}_{2} \mathrm{O}_{3}(\%)+\mathrm{Fe}_{2} \mathrm{O}_{3}(\%)$ values (average 53.26\%) and $\mathrm{CaO}$ (\%) was more than $10 \%$ (on average 22.95\%) (Table 3 and Fig. 3). Based on these values, fly ashes were now classified as $\mathrm{C}$ class, which had high calcareous and pozzolanic characteristics. In addition, the concentration of some heavy metals has also changed in the fly ash samples. For example, concentration of arsenic in the fly ash was about 70 ppm in 2006 [1] (Fig. 4). After the addition of limestone to the process in 2007, the concentration of arsenic increased to levels exceeding $100 \mathrm{ppm}$ level (Fig. 5). The concentration of $\mathrm{Zn}$ has also changed. Concentration of $\mathrm{Zn}$ was around $110 \mathrm{ppm}$ in 2006, whereas this value

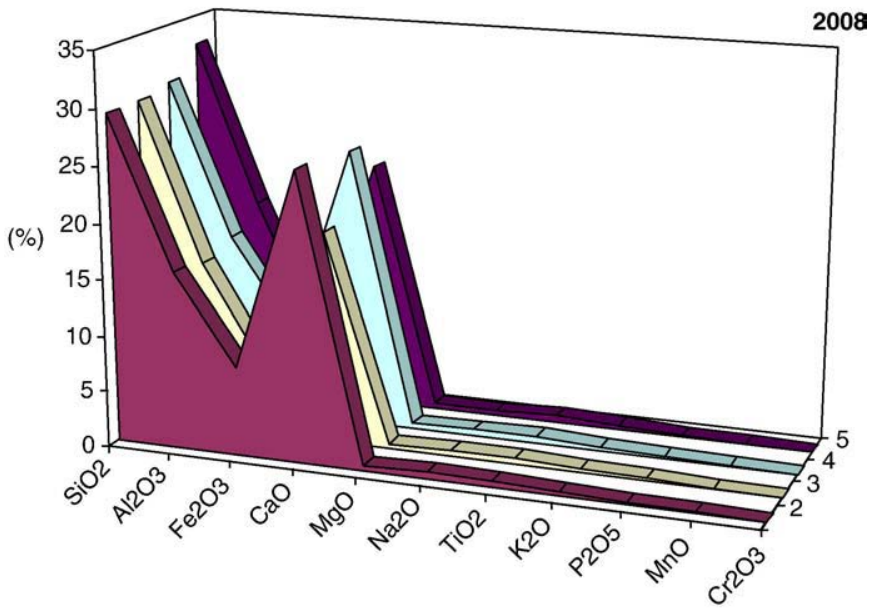

Fig. 3. Chemical composition of fly ash in Çan Thermal Power Plant.

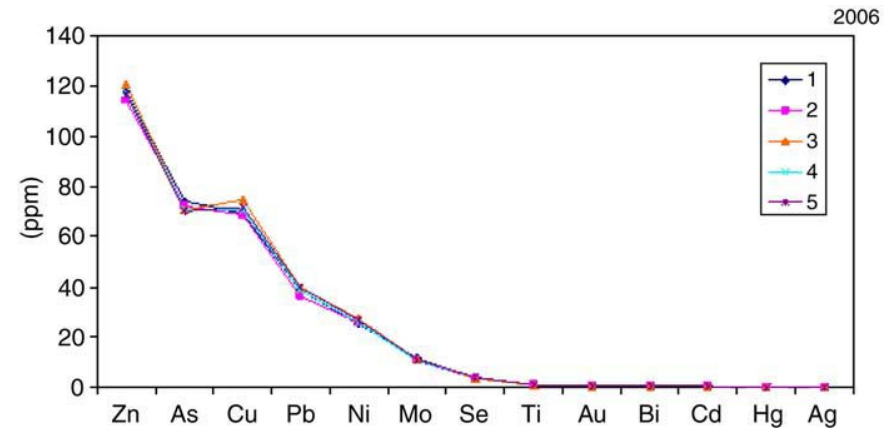

Fig. 4. Component of heavy metals in fly ash in Çan Thermal Power Plant.

decreased to $65 \mathrm{ppm}$ in 2008. These results show that using the fluidized bed combustor technology the heavy metal contents in ash increases.

Generally fly ash has a characteristic spherical microscopic structure. As the molten droplets of inorganic coal residues cool down, fly ash particles solidify and separate out as spheres, while solidifying around trapped hollow gas bubbles. These hollow spheres, if they are empty, are referred to as cenospheres, which can easily be isolated using flotation and many other industrial applications. In this study, the particular size and the shape of the particles were scanned with the scanning electron microscopy technique with energydispersive X-ray microanalysis (SEM-EDX) and the results are shown in Fig. 6. Morphologically, fly ash consists of irregularly shaped particles. SEM-EDX study implies that typical amorphous components include Al-Ca-Fe-Si with traces of Ti, Mg and Zn (Fig. 7).

The leachates of fly ash form fluidized bed combustor generation have different concentrations at different $\mathrm{pH}$ and temperature values. The results are shown in Table 4. The concentrations of the heavy metals at different $\mathrm{pH}$ and temperature values are also presented in Fig. 8. At $\mathrm{pH}=3$ and at $30^{\circ} \mathrm{C}, \mathrm{Cd}, \mathrm{Cr}, \mathrm{Cu}, \mathrm{Ni}$ and $\mathrm{Zn}$ have the maximum

Table 3

Chemical composition of fly ash from Çan thermal power plant.

\begin{tabular}{|c|c|c|c|c|c|c|c|c|c|c|c|c|}
\hline Sample number & Date & $\mathrm{SiO}_{2}$ & $\mathrm{Al}_{2} \mathrm{O}_{3}$ & $\mathrm{Fe}_{2} \mathrm{O}_{3}$ & $\mathrm{CaO}$ & $\mathrm{MgO}$ & $\mathrm{Na}_{2} \mathrm{O}$ & $\mathrm{TiO}_{2}$ & $\mathrm{~K}_{2} \mathrm{O}$ & $\mathrm{P}_{2} \mathrm{O}_{5}$ & $\mathrm{MnO}$ & $\mathrm{Cr}_{2} \mathrm{O}_{3}$ \\
\hline 2 & 2008 & 29.29 & 15.82 & 7.91 & 25.75 & 0.44 & 0.57 & 0.61 & 0.32 & 0.201 & 0.15 & 0.005 \\
\hline 3 & & 29.31 & 15.16 & 5.97 & 18.96 & 0.43 & 0.57 & 0.57 & 0.39 & 0.322 & 0.11 & 0.003 \\
\hline 4 & & 29.90 & 16.07 & 7.82 & 24.89 & 0.44 & 0.58 & 0.63 & 0.33 & 0.21 & 0.09 & 0.003 \\
\hline 5 & & 32.37 & 17.89 & 5.55 & 22.2 & 0.45 & 0.45 & 0.67 & 0.41 & 0.195 & 0.11 & 0.005 \\
\hline
\end{tabular}




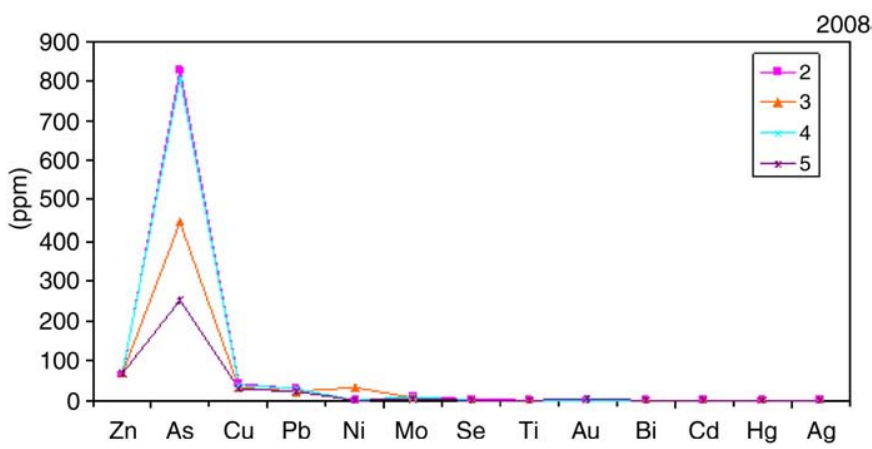

Fig. 5. Component of heavy metals in fly ash in Çan Thermal Power Plant.

concentrations (Fig. 8). Also at $30^{\circ} \mathrm{C}$ and at $\mathrm{pH}=3$, concentrations of Se are high. The maximum concentration is observed for As at $40{ }^{\circ} \mathrm{C}$ and at $\mathrm{pH}=3, \mathrm{pH}=5$ and $\mathrm{pH}=7$. Generally, concentration of $\mathrm{As}$ increase with temperature. At all $\mathrm{pH}$ and temperature values, concentration of $\mathrm{Cd}$ is stable. The minimum concentration of $\mathrm{Zn}$ is observed at $40{ }^{\circ} \mathrm{C}$. Based on the leaching test results, $30^{\circ} \mathrm{C}$ is very important point for elements behavior. As seen in Table 4 , the results show that when $\mathrm{pH}=3$ at $30^{\circ} \mathrm{C}$, some of the heavy metals $(\mathrm{Cr}, \mathrm{Cu}, \mathrm{Ni}$ and $\mathrm{Zn}$ ) have the highest concentration values. When $\mathrm{pH}$ value is same but temperature is changed from $30^{\circ} \mathrm{C}$ to $40^{\circ} \mathrm{C}, \mathrm{Cr}, \mathrm{Cu}, \mathrm{Ni}$ and $\mathrm{Zn}$ concentrations have the lowest values. The maximum concentration is observed for Se at $30^{\circ} \mathrm{C}$ and at $\mathrm{pH}=5$. Also the maximum
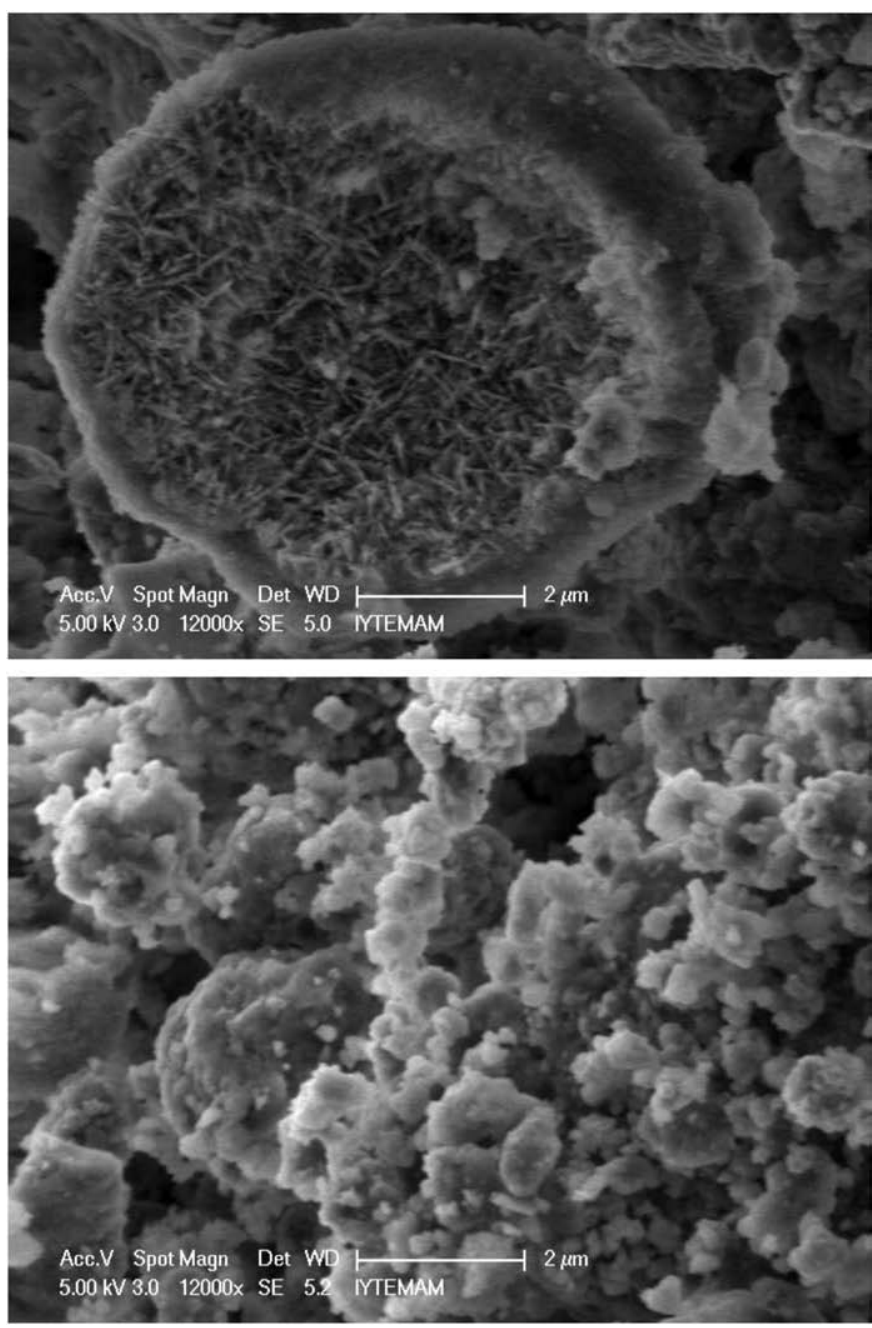

Fig. 6. Selected SEM images of fly ash from Çan Thermal Power Plant. concentration of As can be seen at $40^{\circ} \mathrm{C}$ and at $\mathrm{pH}=3$. Ni passed to the leachate liquid more than any other heavy metals at $\mathrm{pH}=3$, when temperatures are between $20^{\circ} \mathrm{C}$ and $30^{\circ} \mathrm{C}$.

In Fig. 9, changes in all heavy metal concentrations at different $\mathrm{pH}$ values are shown. At $\mathrm{pH}=5$ and at $40{ }^{\circ} \mathrm{C}$, As has the maximum concentration. Also at $20^{\circ} \mathrm{C}$, concentrations of $\mathrm{Zn}, \mathrm{Cu}, \mathrm{Ni}$ and Se are high. Generally, concentration of Se decreases with temperature. At all $\mathrm{pH}$ and temperature values, concentration of $\mathrm{Cd}$ are stable and concentration of $\mathrm{Co}$ is under $0.2 \mathrm{ppm}$. Generally concentration of some element such as $\mathrm{Zn}$ and $\mathrm{Ni}$ has a maximum concentration at $30{ }^{\circ} \mathrm{C}$. Based on the leaching test results $30^{\circ} \mathrm{C}$ is very important point for the elements behavior.

The investigated Çan coal samples have relatively high total sulfur (maximum 12.2\%) and a broad range of ash contents (3.2 to $44.6 \% \mathrm{db}$ ). These parameters are negatively affected their quality. When the content of $\mathrm{As}, \mathrm{Cu}, \mathrm{Co}$ and $\mathrm{Hg}$ increases, also the sulphur contents in coal increase. The determined high concentration of $U$ and $\mathrm{V}$ in the Çan coal samples may be particularly important in the region, since these elements are enriched 10 to 20 times in the combustion residues, especially in the fly ash, compared to the feed coal [27].

\section{Conclusions}

The coal combustion thermal power plants all over the world can be major sources that generate huge quantities of solid wastes. Most part of this waste contains fly ash, which can environmentally affect the ecosystems. But, the thermal power plant wastes in the world (especially the fly ashes) can be utilized in many ways. Before using such fly ash wastes, the permeability, leachability and toxicity characteristics should be determined, besides the chemical properties. Despite establishment of the waste disposal area is new, especially As value has already exceeded the normal values (31.36 ppm). This may cause problems for the human health. For these reasons, the waste disposal area must be regulated carefully and precautions should be taken against any leachability of the waste water to the underground.

The results showed that water temperature, $\mathrm{pH}$ and limestone were the most important factors affecting the leaching properties of the fly ash from the fluidized bed combustor generation. Also this kind of power generation has a strong influence on the heavy metal contents of the fly ash. In addition, the result indicate that concentration of As and Se is more leachable than the other heavy metals in ash.

\section{Acknowledgement}

This study has been funded by the Scientific and Technical Research Council of Turkey (TÜBITAK) under the project number of 106Y041. The authors would like to express their gratitude to the Turkish Academy of Sciences (TÜBA) for providing the financial aid. Also we thank to Ozgur OZAY for help during the lab study.

\section{References}

[1] A. Baba, G. Gurdal, F. Sengunalp, O. Ozay, Effects of leachant temperature and pH on leachability of metals from fly ash: case study: Can Thermal Power Plant, province of Çanakkale, Turkey, Environ. Monit. Assess. 139 (1-3) (2008) 287-298.

[2] A. Baba, Investigation of environmental geology of the Yatagan (Mugla-Turkey) thermal power plant waste. Ph.D. Thesis, Dokuz Eylul University. 2000.

[3] A.I. Zouboulis, R. Tzimou-Tsitouridou, Fly ash utilization in environmental engineering the case of Greece, reclamation, treatment and utilization of coal mining wastes, Rainbow, Balkema, Rotterdam, 1990, pp. 493-499.

[4] A. Baba, Geochemical assessment of environmental effects of ash from Yatagan (Mugla-Turkey) thermal power plant, Water Air Soil Poll. 144 (2003) 3-18.

[5] A. Baba, A. Kaya, Y. Birsoy, The effect of Yatagan thermal power plant (MuglaTurkey) on the quality of surface and ground waters, Water Air Soil Poll. 149 (2003) 93-111. 

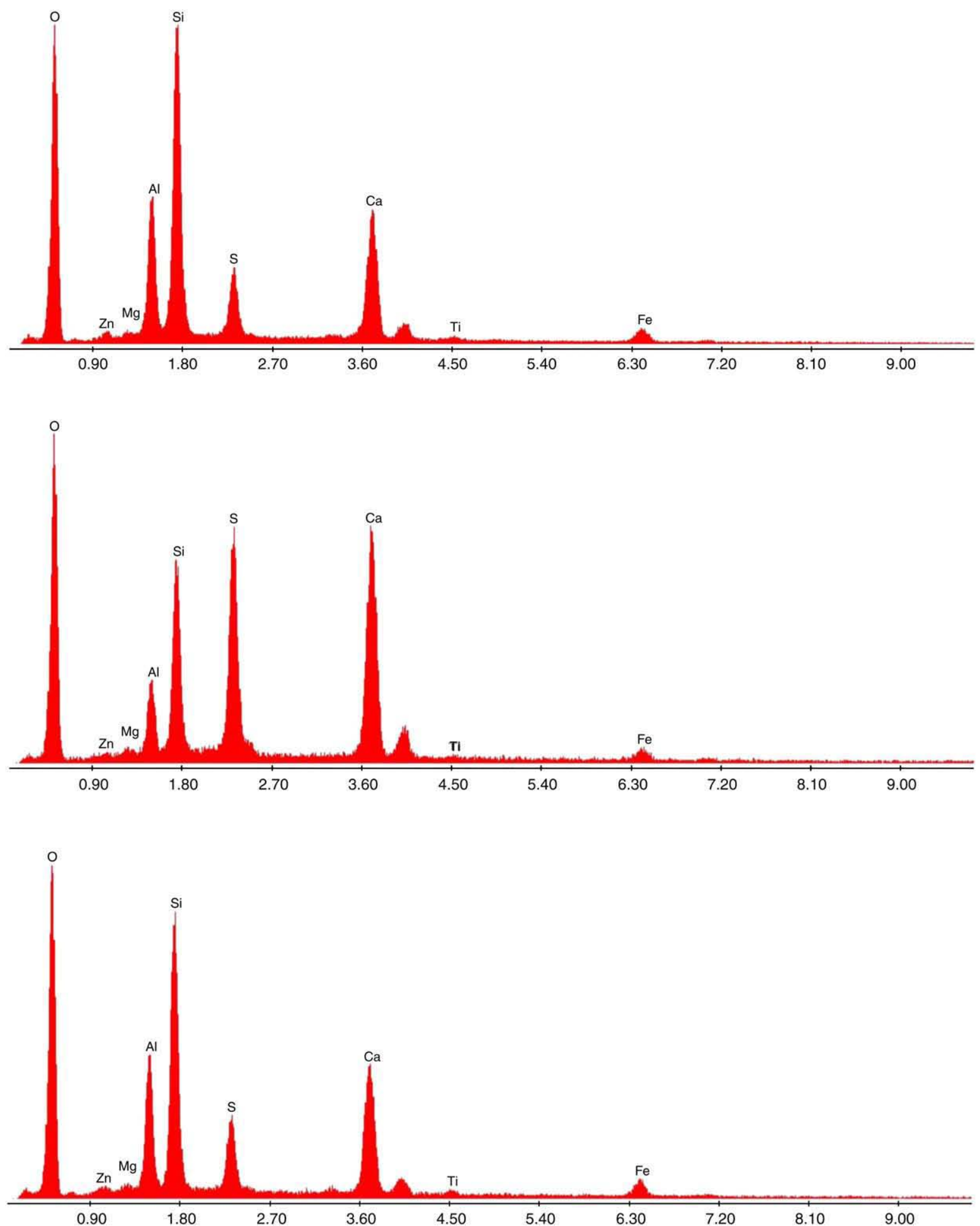

Fig. 7. Selected examples of SEM-EDX traces of fly ash from Çan Thermal Power Plant.

[6] A. Baba, A. Kaya, Leaching characteristics of solid wastes from thermal power plants of Western Turkey and comparison of toxicity methodologies, J. Environ. Manage. 73 (2004) 199-207.

[7] J.A. Campbell, J.C. Laul, K.K. Neilson, R.D. Smith, Separation and chemical characterization of finely-sized fly ash particles, Anal. Chem. 50-8 (1978) 1032-1040.

[8] R.L. Davison, D.F.S. Natusch, J.R. Wallace, C.A. Evans Jr., Trace elements in fly ash dependence of concentration on particle size, Environ. Sci. Technol. 8-13 (1974) 1107-1112.

[9] J.W. Kaakinen, R.M. Jorden, M.H. Lawasani, R.E. West, Trace element behavior in coal-fired power plant, Environ. Sci. Technol. 9-9 (1975) 862-868.

[10] D.H. Klein, A.W. Andren, J.A. Carter, J.F. Emery, C. Feldman, W. Fulkerson, Pathways of thirty seven trace elements through coal-fired power plant, Environ. Sci. Technol. 9-10 (1975) 973-978.
[11] A. Mandal, D. Sengupta, Characterization of fly ash from coal-based thermal power station at Kolaghat-possible environmental hazards, Indian J. Env. P. 228 (2002) 885-891.

[12] L.E. Wangen, M.D. Williams, Elemental deposition downwind of a coal-fired power plant, Water Air Soil Poll. 10 (1978) 33-44.

[13] N. Selçuk, A. Batu, O. Oymak, Fluidized bed combustion, Proc. of 17th Int. Conf. on fluidized bed combustion; ASME, Paper no. FBC2003-109 (in CD-ROM), 2003.

[14] A. Baba, G. Gurdal, Concentration of heavy metals in fly ash from Çan coal combustion thermal power plant (Çanakkale-Turkey)- II, Chinese J. Geochem. 25 (2006) 53.

[15] B. Baba, D. Save, O. Gündüz, G. Gürdal, M. Bozcu, S. Sülün, H. Özcan, O. Hayran, H. İkişık, L. Bakırcı, The assessment of mining activities in Çan coal district from medical geology perspective. TUBITAK Project (in Turkish), No. 106Y041, 2008, 338p. 
Table 4

Concentration of heavy metals at different $\mathrm{pH}$ and temperature values in fly ash from CTPP.

\begin{tabular}{|c|c|c|c|c|c|c|c|c|c|c|c|c|}
\hline \multirow{2}{*}{$\begin{array}{l}\text { Heavy metals } \\
(\mathrm{ppm})\end{array}$} & \multicolumn{3}{|l|}{$10^{\circ} \mathrm{C}$} & \multicolumn{3}{|l|}{$20^{\circ} \mathrm{C}$} & \multicolumn{3}{|l|}{$30{ }^{\circ} \mathrm{C}$} & \multicolumn{3}{|l|}{$40{ }^{\circ} \mathrm{C}$} \\
\hline & $\mathrm{pH}=3$ & $\mathrm{pH}=5$ & $\mathrm{pH}=7$ & $\mathrm{pH}=3$ & $\mathrm{pH}=5$ & $\mathrm{pH}=7$ & $\mathrm{pH}=3$ & $\mathrm{pH}=5$ & $\mathrm{pH}=7$ & $\mathrm{pH}=3$ & $\mathrm{pH}=5$ & $\mathrm{pH}=7$ \\
\hline Cadmium (Cd) & 0.5 & 0.5 & 0.4 & 0.5 & 0.5 & 0.4 & 0.5 & 0.5 & 0.4 & 0.5 & 0.5 & 0.3 \\
\hline Cobalt (Co) & $<0.2$ & $<0.2$ & $<0.2$ & $<0.2$ & $<0.2$ & $<0.2$ & $<0.2$ & $<0.2$ & $<0.2$ & $<0.2$ & $<0.2$ & $<0.2$ \\
\hline Chromium (Cr) & 14.9 & 18.7 & 9.9 & 19.9 & 18.7 & 8.8 & 23.1 & 17.3 & 9.8 & 11.0 & 17.8 & 8.1 \\
\hline Copper $(\mathrm{Cu})$ & 7.9 & 11.4 & 10.5 & 23.0 & 13.8 & 10.6 & 28.1 & 12.3 & 11.2 & 9.6 & 9.3 & 10.0 \\
\hline Nickel (Ni) & 4.9 & 13.1 & 1.7 & 117.8 & 12.3 & 2.5 & 135.4 & 6.3 & 2.7 & 3.9 & 2.3 & 2.6 \\
\hline Lead $(\mathrm{Pb})$ & $<1$ & $<1$ & $<1$ & $<1$ & $<1$ & $<1$ & $<1$ & $<1$ & $<1$ & $<1$ & $<1$ & $<1$ \\
\hline Selenium (Se) & 12.2 & 9.7 & 8.2 & 11.7 & 11.3 & 8.8 & 11.4 & 13.1 & 9.5 & 11.3 & 11.6 & 88. \\
\hline Zinc $(\mathrm{Zn})$ & 13.8 & 13.0 & 15.6 & 17.3 & 12.8 & 13.1 & 18.5 & 17.9 & 14.3 & 5.5 & 6.6 & 12.9 \\
\hline Arsenic (As) & 42.6 & 17.6 & 30.4 & 26.9 & 18.3 & 33.9 & 37.7 & 21.5 & 34.5 & 43.3 & 34.3 & 35.7 \\
\hline
\end{tabular}

Cd

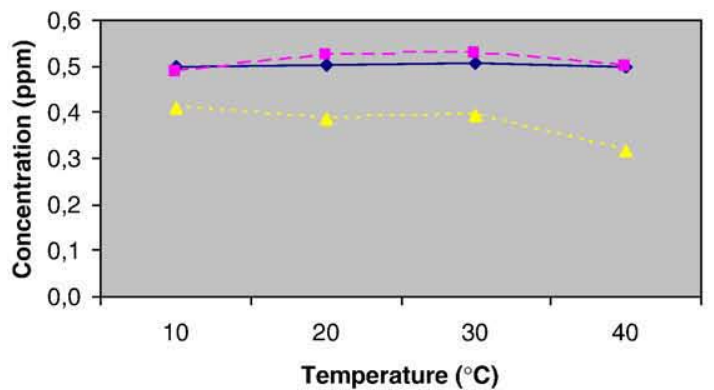

$\mathrm{Cr}$

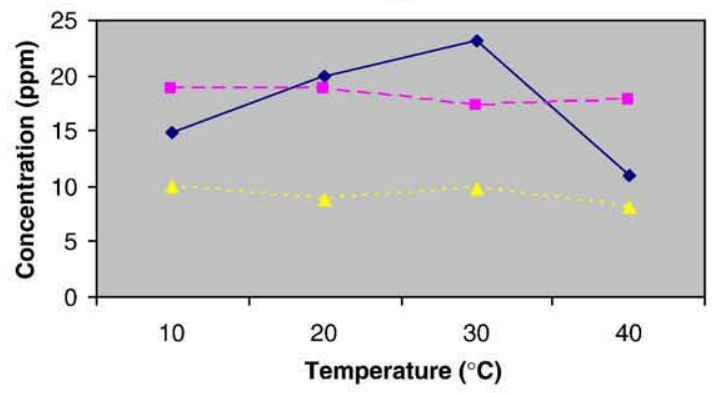

$\mathrm{Cu}$

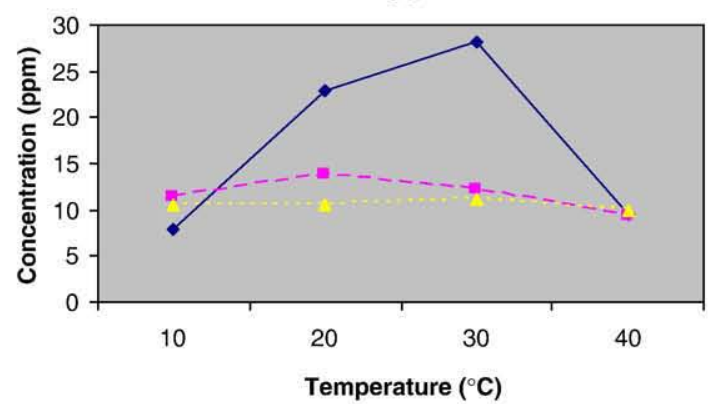

$\mathrm{Ni}$

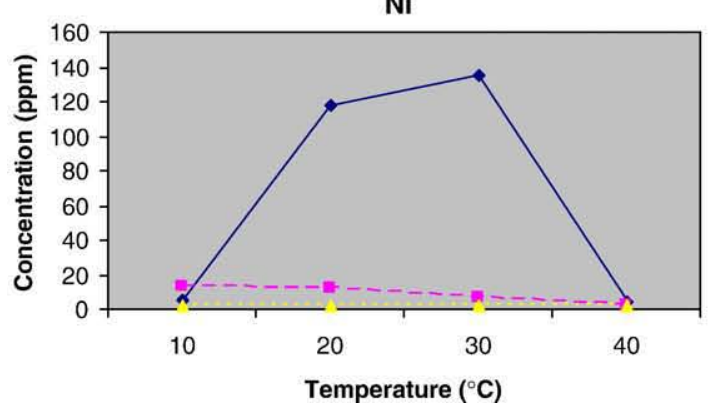

Se

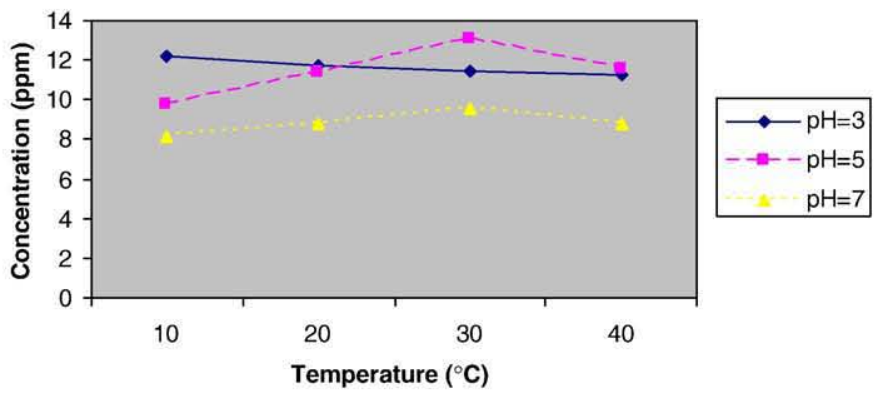

$\mathrm{Zn}$

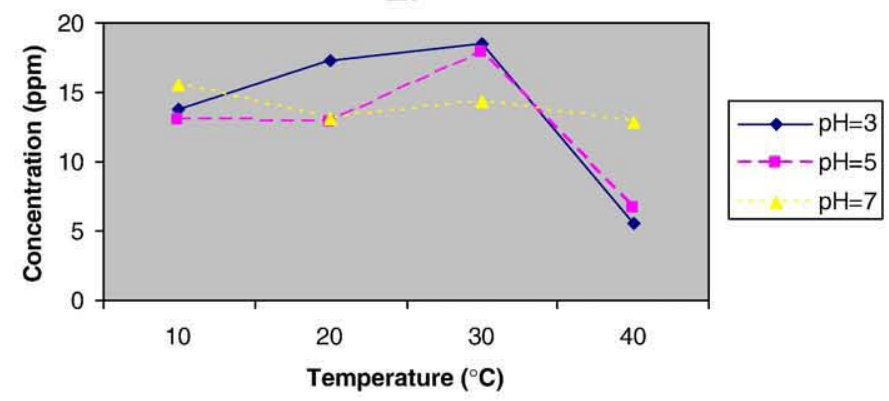

As

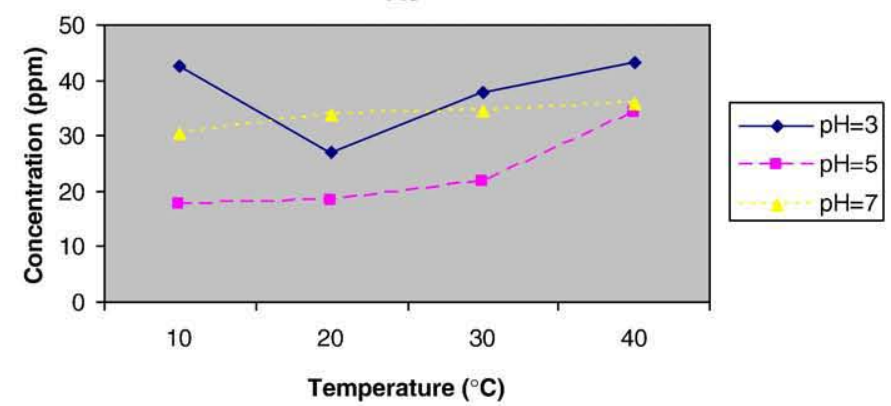

Fig. 8. Concentration of heavy metals in different $\mathrm{pH}$ and temperature. 


\section{$\mathrm{pH}=5$}
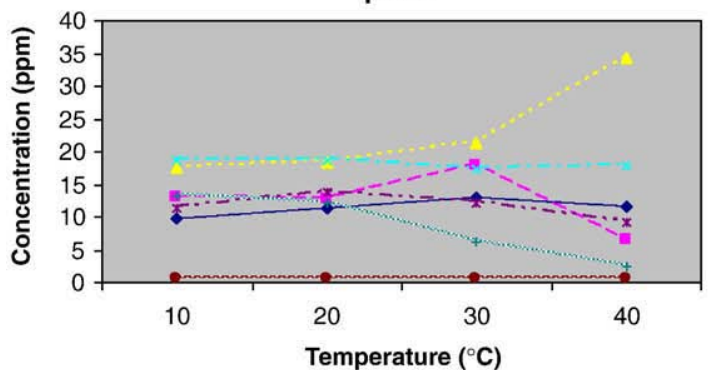

$\mathrm{pH}=3$
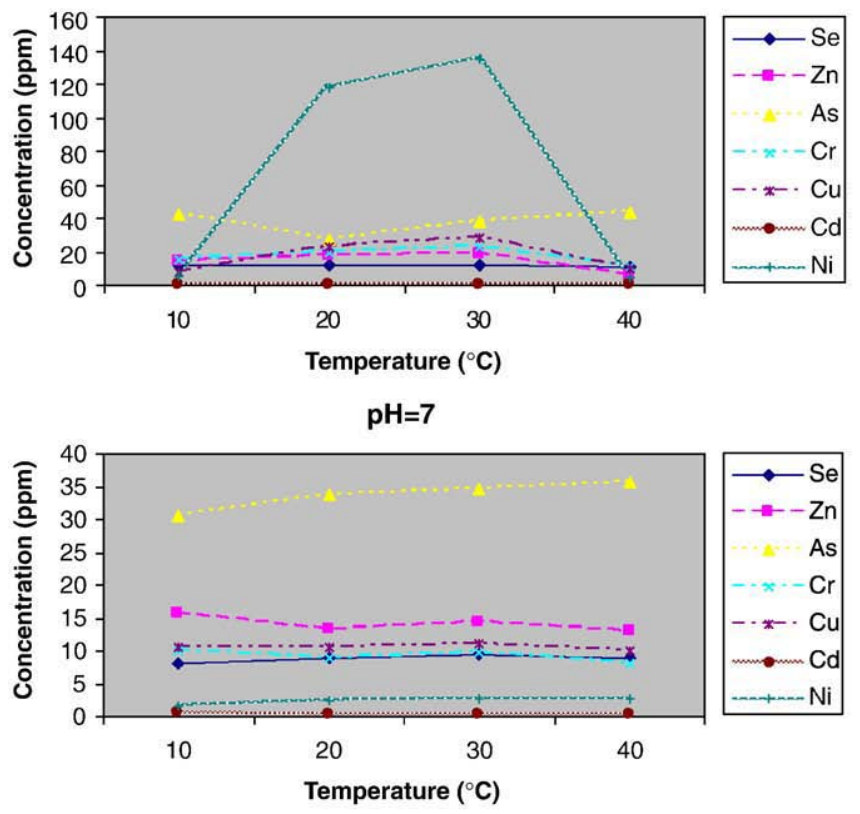

Fig. 9. Heavy metals concentrations in different $\mathrm{pH}$ values.
[16] R.B. Finkelman, The use of modes of occurrence information to predict the removal of the hazardous air pollutants, Int. J. Coal Geol. 12 (4) (1994) 132-134.

[17] R.B. Finkelman, Modes of occurrence of environmentally-sensitive trace elements of coal, in: D.J. Swaine, F. Goodarzi (Eds.), Environmental aspects of trace elements of coal, Kluwer Academic Publishers, the Netherlands, 1995, pp. 24-50.

[18] D.J. Swaine, Why trace elements are important, Fuel Process. Technol. 65-66 (2000) 21-33.

[19] M. Xu, R. Yan, C. Zheng, Y. Oiao, Status of trace element emission in a coal combustion process: a review, Fuel Process. Technol. 85 (2003) 215-237.

[20] G. Gürdal, Geochemistry of trace elements in Çan coal (Miocene), Çanakkale, Turkey, Int. J. Coal Geol. 74-1 (2008) 28-40.

[21] G. Gürdal, Characterization of Çan-Etili (Çanakkale) Miocene coals. 62nd Geological Kurultai of Turkey, 13-17 April 2009, MTA, Ankara. Abstracts Book, 1, 2009, 347p.

[22] G. Gürdal, A. Baba, Determination of potential hazardous elements in coal (Canakkale-Turkey)- I, Chinese J. Geochem. 25 (2006) 52.

[23] M. Bozcu, F. Akgün, G. Gürdal, A. Bozcu, S. Yeşilyurt-Kapan, Ö. Karaca, Sedimentologic, petrologic, geochemical and palinological examination of Çan Yenice Bayramic (Canakkale) Lignite Basin. TUBITAK Project (in Turkish), No 105Y114, 2008, 222p.

[24] ASTM, American Society for Testing and Materials, Annual book of ASTM standards, USA, 1991.

[25] ASTM, American Society for Testing and Materials, Annual book of ASTM standards. Section 5: Petroleum Products, Lubricants and Fossil Fuels.5.05: Gaseous Fuels: Coal and Coke, 1991.

[26] E. Stach, M.-Th. Mackowsky, M. Teichmüller, G.H. Tayler, D. Chandra, R. Teichmüller Stach's Textbook of Coal Petrology, Gebrüder, Borntraeger, Berlin, 1982535 pp.

[27] P.K. Mukhopadhyay, F. Goodarzi, A.L. Gills, K.S. MacNeil, D.J. Smith, Comparision of coal composition and elemental distribution in selected seams of the Sydney and Stellarton Basins, Nova Scotia, Eastern Canada, Int. J. Coal Geol. 37 (1998) 113-141.

[28] C.A. Palmer, E. Tuncalı, K.O. Dennen, T.C. Coburn, R.B. Finkelman, Characterization of Turkish coals:a nationwide perspective, Int. J. Coal Geol. 60 (2004) 85-115. 